\title{
Pemanfaatan Mol Limbah Sayuran sebagai Pupuk Organik Cair pada Tanaman Padi (Oryza sativa L.)
}

\author{
Nana Ariska ${ }^{1}$, Yusrizal $^{2}$, Jasmi $^{3}$ \\ 1,2,3 Jurusan Agroteknologi, Universitas Teuku Umar \\ Email: nanaariska@utu.ac.id \\ Email: yusrizal@utu.ac.id \\ Email: jasmi@utu.ac.id
}

Submitted: 11 November 2019 Revised: 18 November 2019 Accepted: 23 November 2019

\begin{abstract}
This service aims to provide information so that farmers can utilize and apply liquid organic fertilizer from vegetable waste (MOL) to rice plants in the village of Cot Darat, Sama Tiga District, West Aceh Regency. The method used to achieve these objectives is through counseling using participatory and on-site practice. The stages of its implementation are through counseling methods in the form of material exposure on vegetable waste MOL, discussion of farmer groups on site, training in processing organic waste into biocomposers together with farmer groups. The results of this service show that the level of knowledge and understanding of technology for processing vegetable waste into organic fertilizer can be absorbed (controlled) by rice farmers. All members of the group consist of various ages ranging from 30 to 50 years. One indicator in determining work productivity in conducting business development is the age level, where the age of farmers who are relatively young is stronger, work smart, easy to accept new innovations.
\end{abstract}

Keywords: Liquid Organic Fertilizer, Vegetable Waste, MOL, Rice Plants.

\begin{abstract}
Abstrak
Pengabdian ini betujuan memberi informasi agar petani dapat memanfaatkan dan menerapkan pupuk organik cair dari limbah sayuran (MOL) terhadap tanaman padi di desa Cot Darat Kecamatan Sama Tiga Kabupaten Aceh Barat. Metode yang dipakai untuk mencapai tujuan tersebut adalah melalui penyuluhan menggunakan secara partisipatif dan praktek di lokasi. Tahapan pelaksanaannya adalah melalui metode penyuluhan berupa pemaparan materi mengenai MOL limbah sayuran, diskusi kelompok tani di lokasi, Pelatihan pengolahan limbah organik menjadi biokomposer bersama-sama dengan kelompok tani. Hasil dari pengabdian ini yaitu menunjukkan bahwa tingkat pengetahuan dan pemahaman teknologi pengolahan limbah sayuran menjadi pupuk organik dapat diserap (dikuasai) oleh para petani padi seluruh anggota kelompok terdiri dari berbagai macam usia mulai dari 30 hingga 50 tahun. Salah satu indikator dalam menentukan produktivitas kerja dalam melakukan pengembangan usaha adalah tingkat umur, dimana umur petani yang berusia relatif muda lebih kuat bekerja, cekatan, mudah menerima inovasi baru.
\end{abstract}

Kata Kunci: Pupuk Organic Cair, MOL, Limbah Sayuran, Tanaman Padi

\section{PENDAHULUAN}

Kecamatan

Samatiga

merupakan salah satu kecamatan yang dikenal sebagai penghasil padi di kabupaten Aceh Barat. Jumlah populasi padi di Sama Tiga dengan luas lahan $3.516 \mathrm{~m}^{2}$ hanya $2.664 \mathrm{~m}^{2}$ luas lahan yang dapat dipanen pada tahun 2016 mencapai 6.80 Ton/ha (BPS, 2017). Produksi padi dalam pelaksanaannya tidak selalu berjalan dengan baik. Hal tersebut dapat dipengaruhi oleh tingkat produksi padi di daerah tersebut terkadang 
berbanding terbalik dengan luas lahan padi yang ditanam sehingga produksi tidak terpenuhi karena kebutuhannya semakin meningkat.

Desa Cot Darat merupakan salah satu desa dalam Kecamatan Samatiga Kabupaten Aceh Barat dengan padi sebagai komoditi terbesarnya dan mempunyai lahan yang luas. Masyarakat Desa Cot Darat sebagian besar mata pencahariannya sebagai petani padi.

Salah satu factor yang menyebabkan rendahnya produksi padi adalah pada umumnya petani masih membudidayakannya tidak sesuai aturan, seperti pemupukan yang tidak sesuai dengan anjuran serta masih banyaknya petani mengunakan bahan-bahan kimia dalam pelaksanaannya.

Saat ini petani di Desa Cot Darat masih banyak yang menggunakan pupuk kimia dibandingkan dengan pupuk organik. Alasannya adalah karena kandungan hara pupuk kimia lebih tinggi, mudah diperoleh secara instan walau dengan harga yang tinggi. Kesulitan mendapatkan pupuk kandang yang cukup saat musim tanam membuat petani harus tergantung terhadap pupuk kimia. Dampak penggunaan pupuk kimia pada lahan tersebut yang dilakukan secara terus menerus mengakibatkan semakin berkurangnya kandungan bahan organik di dalam tanah, kesuburan tanah menurun, sehingga hasil penen juga menurun. Akibatnya, selain tidak ekonomis, pemupukan menggunakan bahan kimia ternyata dapat menyebabkan terjadinya pencemaran terhadap lingkungan, baik pencemaran tanah maupun air. Oleh sebab itu perlu pemanfaatan bahan organik yang aman, efektif pengaruhnya bagi tanaman, dan ada di sekitar kita sebagai penganti pupuk kimia, salah satunya adalah pupuk organic dengan bahan dasar limbah sayuran.

Menurut Amrullah (2015) limbah sayuran pasar adalah bahan yang dibuang dari usaha memperbaiki penampilan sayur mayur yang akan dipasarkan. Limbah sayuran biasanya terdiri dari bahan-bahan yang memiliki kandungan air yang cukup banyak, sehingga mudah dan cepat membusuk.

Utama dan Mulyanto (2009) mengatakan, pemanfaatan dengan cara daur ulang yang ramah lingkungan, mudah dan murah memerlukan cara yang tepat untuk mengatasi persoalan tersebut. Penanganan limbah sayuran yang dianggap efisien, mudah, murah, ramah lingkungan dan menghasilkan pendapatan tambahan salah satunya adalah dengan menjadikan limbah sayuran sebagai pupuk organik kompos. 
Pembuatan kompos dari limbah sayuran , adalah satu dari beberapa cara pemanfaatan sampah sayuran yang terus menumpuk. Nisa, dkk (2016) menjelaskan sampah sayuran banyak mengandung mineral nitrogen, fosfor, kalium (K) dan B12.

Dari uraian diatas, diperlukan pengabdian untuk memberi informasi agar petani dapat memanfaatkan dan menerapkan pupuk organik cair dari limbah sayuran (MOL) terhadap tanaman padi di desa Cot Darat Kecamatan Sama Tiga Kabupaten Aceh Barat.

\section{METODE PELAKSANAAN}

Kegiatan ini akan dilakukan dengan metode pelatihan berupa pemaparan materi mengenai MOL limbah sayuran. Dalam melaksanakan program pengabdian masyarakat pada petani padi ada beberapa solusi yang coba ditawarkan kepada petani tersebut yaitu:

1. Memberikan informasi dan penyuluhan bagi petani mengenai pentingnya peran dan kandungan MOL terutama limbah sayuran.
2. Memberikan informasi dan penyuluhan bagi padi mengenai manfaat penggunaan MOL limbah sayuran terhadap produksi padi.

\section{HASIL DAN PEMBAHASAN}

Hasil menunjukkan bahwa tingkat pengetahuan dan pemahaman teknologi pengolahan limbah sayuran menjadi pupuk organik dapat diserap (dikuasai) oleh para petani padi. Petani yang hadir berjumlah 20 orang yang berjenis kelamin perempuan dan laki-laki. Seluruh anggota kelompok terdiri dari berbagai macam usia mulai dari 30 hingga 50 tahun. Salah satu indikator penentuan produktivitas kerja dalam melakukan pengembangan usaha adalah tingkatan umur, dimana umur petani yang berusia relatif muda lebih kuat bekerja, cekatan, dan mudah menerima inovasi baru. Berikut disajikan pada Tabel 1. Karekteristik Umur Rata-Rata Petani Padi di Kecamatan Sama Tiga.

Tabel 1. Karakteristik Umur Rata-Rata Petani Padi Kecamatan Sama Tiga, Kabupaten Aceh Barat

\begin{tabular}{lll}
\hline No & Umur (Tahun) & Frekuensi (Orang) \\
\hline 1 & $20-30$ & 15 Orang \\
2 & $30-40$ & 5 Orang \\
\hline Jumlah & 20 Orang \\
\hline
\end{tabular}

Sumber: Data Pengabdian Dari Lapangan, 2019 
Penyampaian materi tentang penggunaan pupuk organik cair kepada para petani padi di

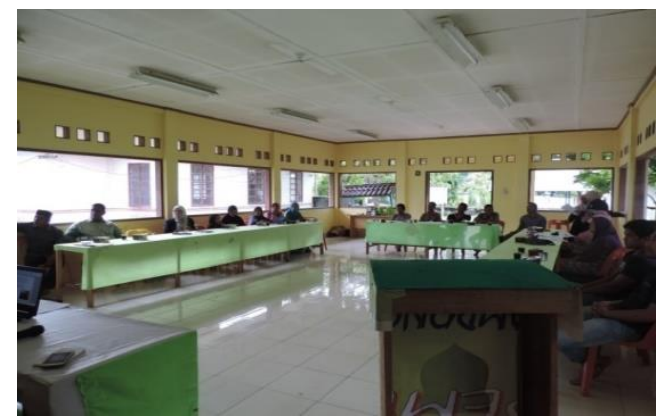

Gambar 1. Keadaan di Lokasi

Pengabdian dalam mengikuti penyampaian Materi

Pupuk organik cair (MOL) yang digunakan pada pengabdian merupakan pupuk dari hasil limbah organik. Limbah tersebut berasal dari hasil pelapukan jaringan tanaman atau bahan tanaman seperti jerami, daun-daunan dan rumputrumputan termasuk sayuran yang berupa limbah organik yang mudah diperoleh dari lingkungan sekitar, didaur ulang dan dirombak dengan bantuan mikroorganisme perombak seperti bakteri dan cendawan menjadi unsur-unsur hara yang tersedia yang dapat diserap oleh tanaman.

Salah satu upaya peningkatan hasil tanaman padi (Oryza sativa L.) adalah melalui penerapan System of Rice Intensification (SRI), suatu sistem pengelolaan tanaman, tanah dan air menjadi suatu sistem dalam satu rangkaian yang saling
Kecamatan Sama Tiga dapat dilihat pada gambar 1 dan 2 berikut.

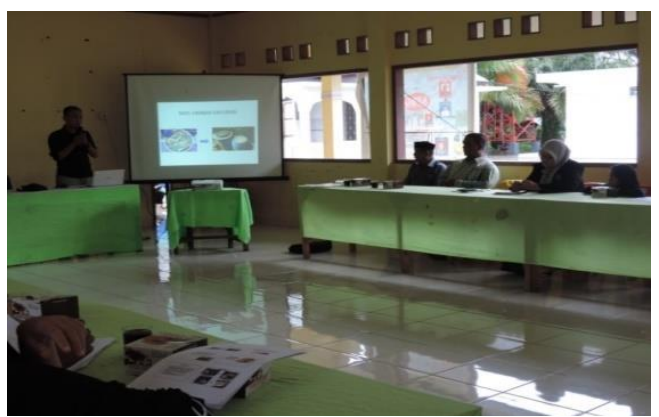

Gambar 2. Pembukaan \&

Penyampaian Arahan dari

Pemateri \& Instansi di Tempat

Pengabdian

mempengaruhi satu sama lain. Dalam praktik pemupukan dengan menerapkan pengelolaan lahan yang ramah lingkungan serta mampu memelihara kesuburan tanah, menjaga kelestarian lingkungan dan dapat mempertahankan serta meningkatkan produktivitas tanah melalui pemupukan yaitu menggunakan Mikroorganisme Lokal (MOL) dalam penerapan SRI organik untuk memperbaiki pertumbuhan, hasil dan melindungi tanaman dari hama penyakit (Chapagain et al. 2011; NOSC 2013).

Pupuk organik cair dapat berperan sebagai pengikat agregat primer menjadi agregat sekunder tanah. Keadaan ini memengaruhi penyimpanan unsur hara, penyediaan air, aerasi atau udara tanah, dan menstabilkan suhu tanah tanah. Bahan organik yang 
mengandung banyak karbon dan nitrogen, seperti jerami dan limbah sayuran lebih besar pengaruhnya pada perbaikan sifat-sifat fisik tanah sehingga memiliki fungsi yaitu penyediaan unsur hara seperti nitrogen, fosfor dan kalium yang sangat dibutuhkan oleh tanaman.

Sesuai dengan pendapat Zahid (2009), unsur hara nitrogen dapat merangsang pertumbuhan tanaman secara keseluruhan melalui bagian dari sel (organ) tanaman itu sendiri yang berfungsi untuk sintesa asam amino dan protein dalam jaringan tanaman, merangsang pertumbuhan vegetatif daun tanaman dan pertumbuhan vegetatif batang tanaman. Tanaman yang kekurangan unsur nitroen gejalanya adalah pertumbuhan kerdil, daun berwarna hijau kekuningan, daun sempit, pendek dan tegak, daun-daun tua cepat menguning dan rontok. Fosfat berfungsi untuk pengangkutan energi dari hasil metabolisme tanaman, merangsang pembungaan dan pembuahan, merangsang pertumbuhan akar, merangsang pembentukan biji, merangsang pembelahan sel tanaman serta memperbesar jaringan sel tumbuhan. Tanaman yang kekurangan unsur fosfor gejalanya : pembentukan buah serta biji berkurang, daun berwarna keunguan atau kemerahan (kurang sehat). Unsur hara kalium berfungsi dalam proses fotosintesa, pengangkutan hasil asimilasi tanaman, enzim dan mineral termasuk air. Meningkatkan daya tahan tanaman terhadap penyakit. Kekurangan unsur hara kalium menyebabkan batang dan daun menjadi lemas, daun berwarna hijau gelap dan kebiruan, ujung daun menguning dan kering, timbul bercak kecoklatan pada pucuk daun tanaman.

Pengenalan tentang kesuburan tanah oleh peserta cukup bagus, Petani padi memahami karakteristik padi sebagai tanaman semusim yang ditanam di agroekosistem sawah yang tidak stabil sehingga mudah muncul masalah baik hama, kesuburan tanah dan produksi. Sebagian para petani belum mengetahui pentingnya penggunaan pupuk organik cair dan beberapa kendala di lapangan terkait pertumbuhan dan produksi tanaman. Petani dapat mengenali gejala tersebut tetapi belum dapat menanganinya secara efektif dan efisien, sehingga Pembuatan pupuk organik cair melalui proses pengomposan berbahan baku limbah sayuran dapat dijadikan usaha oleh petani dalam meningkatkan produksi dan pendapatan petani. 


\section{PENUTUP}

1. Pembuatan pupuk organik cair dari bahan baku limbah sayuran mampu disosialisasikan dengan baik kepada masyarakat khususnya petani padi.

2. Tingkat pengetahuan dan pemahaman teknologi pengelahan limbah sayuran menjadi pupuk organik cair dapat diserap oleh para petani padi.

\section{DAFTAR PUSTAKA}

Amrullah, Fakhri Aji. 2015. Pengaruh Penambahan Berbagai Jenis Sumber Karbohidrat Pada Silase Limbah Sayuran Terhadap Kadar Lemak Kasar, Serat Kasar, Protein Kasar Dan Bahan Ekstrak Tanpa Nitrogen. Skripsi. Lampung: Fakultas Pertanian Universitas Lampung.

Badan Pusat Statistik Kabupaten Aceh Barat, 2017. Luas Tanam, Luas Panen, Produksi dan Rata-Rata Produksi Padi Sawah Kecamatan di Kabupaten Aceh Barat 2016. Aceh Barat : Badan Pusat Statistik.

Budiyanto, M. 2002. Mikrobiologi Terapan. Universitas Muhammadiyah. Malang
Chapagain T., A. Resiman, dan E. Yamaji. 2011. Assessment of System of Rice Intensification (SRI) and conventional practices under organic and inorganic management in Japan. Rice Sci. 18: $311-320$

Lingga, Pinus. 2003. Petunjuk Penggunaan Pupuk. Penebar Swadaya : Jakarta.

Musnamar,Effi Ismawati. 2005. Pupuk Organik:Cair dan Padat,Pembuatan dan Aplikasi.Swadaya:Jakarta.

Ole, M.B.B. 2013. Penggunaan Mikroorganisme limbah sayuran Sebagai Dekomposer Sampah Organik. Tesis. Universitas Atma Jaya Yogyakarta Fakultas Teknobiologi Program Studi Biologi. Yogyakarta.

Samekto, R., 2006. Pupuk Kompos, Yogyakarta: PT. Citra Aji Parama.

Sembiring, Daswati.2015. Efektivitas Berbagai Jenis Aktivator dalam Pembuatan Kompos dari Limbah Kol (Brassica Oleracea) Tahun 2014. Skripsi. Medan:Fakulutas Kesehatan Masyarakat USU.

Utama, CS dan A. Mulyanto. 2009. Potensi Limbah Sayur Pasar Sebagai Starter Fermentasi. Jurnal Kesehatan. Universitas Diponegoro Semarang Vol.2, No. I Juni 2009. 
Zahid, P.B. 1999. Preparation of organik fertilizer fromseaweed and its effect on the growth of some vegetable and ornamental plants. Pakistan. J. of Biol. Sci. 2(4): 1274-1277. 